\title{
LEFTY2 Gene
}

National Cancer Institute

\section{Source}

National Cancer Institute. LEFTY2 Gene. NCI Thesaurus. Code C24356.

This gene is involved in embryogenesis and morphogenesis. It plays a role in the determination of left-right asymmetry. 